\title{
Linking small pelagic dietary shifts with ecosystem changes in the Gulf of Lions
}

\author{
Pablo Brosset ${ }^{1,2, *}$, Baptiste Le Bourg ${ }^{3,5}$, David Costalago ${ }^{4}$, Daniela Bănaru ${ }^{3}$, \\ Elisabeth Van Beveren ${ }^{2}$, Jean-Hervé Bourdeix ${ }^{2}$, Jean-Marc Fromentin ${ }^{2}$, \\ Frédéric Ménard ${ }^{3}$, Claire Saraux ${ }^{2}$ \\ ${ }^{1}$ Université de Montpellier, UMR MARBEC (IRD, Ifremer, UM, CNRS), 34203 Sète cedex, France \\ ${ }^{2}$ IFREMER, UMR MARBEC (IRD, Ifremer, UM, CNRS), 34203 Sète cedex, France \\ ${ }^{3}$ Mediterranean Institute of Oceanography (MIO), Aix-Marseille Université/CNRS/IRD/Université de Toulon, UM 110, \\ 13288 Marseille, France \\ ${ }^{4}$ Department of Ecology, Environment and Plant Sciences, Stockholm University, 10691 Stockhom , Sweden \\ ${ }^{5}$ Present address: Université de Liège, Laboratory of Oceanology, MARE Centre, 4000 Liège, Belgium
}

\begin{abstract}
Since 2008, a severe decrease in size and body condition together with a demographic truncation has been observed in the sardine (secondarily in anchovy) population of the Gulf of Lions (NW Mediterranean Sea). In parallel, sprat biomass, which was negligible before, has increased tenfold. All of these changes have strongly affected the regional fisheries. Using trophic and isotopic data from contrasting periods of low versus high growth and condition, we investigated potential changes in diet and interspecific feeding interactions through time. Evidence of resource partitioning was found between sprat and both anchovy and sardine in 2004 and 2005. Since 2010, the isotopic niches of the 3 species have tended to overlap, suggesting higher risk of competition for food resources. Moreover, the wider trophic niche of sprat indicates higher variability in individual diets. Anchovy and sardine diet varied through time, with a high proportion of large copepods or cladocerans in periods of high growth and condition (1994 and 2007, respectively) versus a dominance of small copepods in the present (2011-2012). Furthermore, an important reduction in prey diversity was also identified in the diet of both anchovy and sardine during the most recent period. Our results support the hypothesis that changes in small pelagic fish growth, size and body condition and ultimately biomass could be due to bottom-up control characterized by changes in food availability and increasing potential trophic competition.
\end{abstract}

KEY WORDS: Trophic ecology $\cdot$ Anchovy $\cdot$ Sardine $\cdot$ Sprat $\cdot$ Dietary overlap $\cdot$ NW Mediterranean

Resale or republication not permitted without written consent of the publisher

\section{INTRODUCTION}

Small pelagic fish species are characterized worldwide by important temporal fluctuations in their abundance and biomass, generally ruled by environmental changes in marine ecosystems (Schwartzlose et al. 1999, Alheit \& Niquen 2004). Bottom-up control, driven by changing ocean conditions, was therefore often proposed as the main hypothesis to explain these regime shifts (Cury \& Shannon 2004), but changes in plankton quantity and quality are difficult to confirm due to a lack of sufficient observations of the planktonic community in both time and space.

In the Gulf of Lions, sardine Sardina pilchardus, W. 1792, anchovy Engraulis encrasicolus, L. 1758 and sprat Sprattus sprattus, L. 1758, the 3 main small pelagic species, act as a critical link between planktonic production and top predators (Bănaru et al. 2013). Additionally, anchovy and sardine support pelagic trawling and purse seine fisheries (between 30 and 
$50 \%$ of the total landings in this area, Bănaru et al. 2013), making them both ecologically and economically essential (Palomera et al. 2007). During the last decade, a decrease in size and body condition was observed for anchovy and sardine, while at the same time, sprat biomass, which had been negligible before, increased tenfold (Van Beveren et al. 2014). These changes made sardine and anchovy commercially less interesting, so that landings dropped dramatically, reaching their lowest values in $150 \mathrm{yr}$ for sardines (Van Beveren et al. 2016). Surprisingly, the recruitment has remained high and these modifications primarily affected the adults, with a disappearance of older age classes, especially for sardine (Van Beveren et al. 2014, Brosset et al. 2015).

Such changes in the small pelagic fish community are far less common than changes in recruitment and might result from selective pressure from fishing or natural predation or modifications in prey availability and/or quality. Yet, fishing pressure does not appear to be the main driver of these changes, as these populations were/are not overfished (GFCM 2014) and exploitation rates have remained low over the last 2 decades (i.e. at around 10 to $20 \%$ on average without exceeding $40 \%$, see Van Beveren et al. 2016). Predation pressure from Atlantic Bluefin tuna, the main top predator of the small pelagic fish in this area, has been recently evaluated to be $<2 \%$ (Van Beveren et al. 2016), indicating that top-down control is unlikely. While predation due to natural predators or fishing remained at low levels for these species, body condition in sardine and anchovy is strongly affected by mesozooplankton abundance (Brosset et al. 2015), pointing to bottom-up control as the most probable source of changes in small pelagic fish in the NW Mediterranean. Unfortunately, plankton records are scarce in the Gulf of Lions, and no time series is currently available to test for such bottom-up control.

Stomach content analysis and stable isotope analysis (SIA) are 2 of the main approaches for investigating feeding habits and trophic interactions (Darnaude et al. 2004, Post et al. 2007). Stomach content analysis documents recently consumed food items and permits a quantitative and qualitative snapshot of the diet (Hyslop 1980). SIA is complementary to stomach content analysis and facilitates an integrated measure of the assimilated food over the previous months depending on the variability of prey and their stable isotope ratios, the fractioning and the isotopic turnover. Values of $\delta^{15} \mathrm{~N}$ may be related to the trophic level of an individual, while the $\delta^{13} \mathrm{C}$ ratio indicates the primary production sources, i.e. the different feeding environments (coastal/oceanic, pelagic/ benthic), used by consumers (Vander Zanden \& Rasmussen 1999, 2001). Combining stomach content analysis and SIA has become an effective tool to investigate changes in trophic structure. Hence, their joint use contributes to the further understanding of how an ecosystem may be affected by changes in interspecific interactions (Caut et al. 2006).

Several studies have provided important information on the feeding habits and diets of these 3 species in the Gulf of Lions (Plounevez \& Champalbert 2000, Costalago et al. 2012, Costalago \& Palomera 2014, Pethybridge et al. 2014, Le Bourg et al. 2015). However, they were usually limited to 1 species or a given period, so that the investigation of potential temporal changes over the last 15 to $20 \mathrm{yr}$ is still missing. The aim of our study was to investigate the hypothesis that recent changes observed in anchovy, sardine and sprat populations in the Gulf of Lions might result from diet changes. In this study, we investigated changes in the feeding habits between periods of contrasting growth and condition (before and after 2008) defined by Van Beveren et al. (2014). In particular, isotopic interspecific overlap, trophic niche width and prey type were examined through time. Given that sardine, sprat and anchovy strongly cooccur in terms of spatial distribution in the Gulf of Lions (Saraux et al. 2014), trophic overlap between species might result in food competition if resources become limited (Hardin 1960). Moreover, the niche width, i.e. an index of prey diversity estimated through the range of $\delta^{15} \mathrm{~N}$ and $\delta^{13} \mathrm{C}$ values or Shannon's diversity, may be used to determine how generalist a population might be in terms of diet and feeding areas (Newsome et al. 2007). Finally, prey species composition might have a strong effect on the energy intake of predators (Beaugrand et al. 2003, Blanchard et al. 2012).

\section{MATERIALS AND METHODS}

\section{Study area}

The Gulf of Lions $\left(42^{\circ} 26^{\prime}-43^{\circ} 40^{\prime} \mathrm{N}, 3^{\circ} 00^{\prime}-5^{\circ} 27^{\prime} \mathrm{E}\right.$; Fig. 1) is located in the northwestern Mediterranean Sea and is characterized by a large continental shelf (Millot 1990). Shallow waters between 0 and $200 \mathrm{~m}$ associated with Rhône River discharge and coastal upwelling due to northern winds support high productivity, making it one of the most productive areas of the Mediterranean Sea (Minas \& Minas 1989, Lefevre et al. 1997). A decreasing trend in the concentration of nutrients occurs from east to west and from 

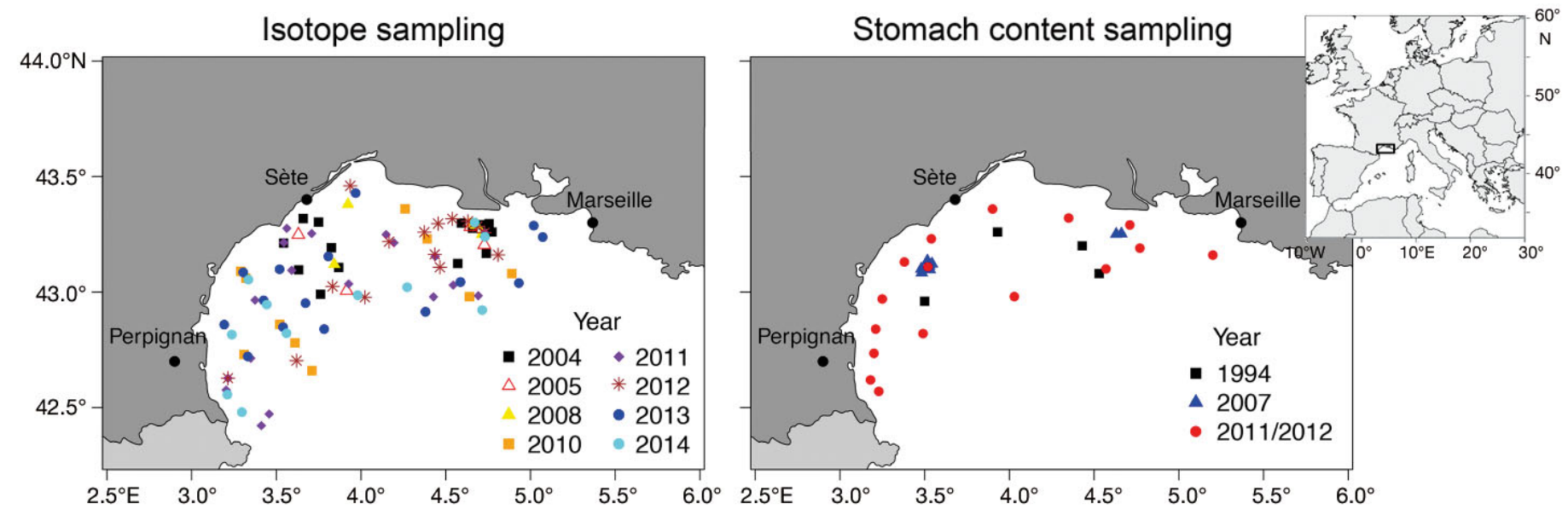

Fig. 1. Sampling sites in the Gulf of Lions (NW Mediterranean Sea). Locations for isotope sampling and stomach content sampling are shown

coastal to deeper waters (Bănaru et al. 2013). The particulate organic matter and phyto- and zooplankton communities at the base of the food webs show inter annual, seasonal and spatial variations in terms of composition and stable isotope ratios in this area (Darnaude et al. 2004, Bănaru et al. 2014, Espinasse et al. 2014). These variations may be related to the terrestrial and anthropogenic river inputs, to currents and wind forcing influencing the hydrography of the area and to changes in the phyto- and zooplankton communities in terms of species composition and size classes (Rau et al. 1990, Harmelin-Vivien et al. 2008, Bănaru et al. 2014).

\section{Sample collection}

Fish and zooplankton samples were collected during Pelagic Mediterranean (PELMED) scientific surveys during the summer under a similar protocol. Fish were sampled with a pelagic trawl with a smallmesh cod-end (mesh length $5 \mathrm{~mm}$, ISO 1107) and towed at an approximate speed of 4 knots over 30 min periods. All specimens were selected randomly from hauls, and their standard length was determined to the nearest $\mathrm{mm}$, as well as their mass (to the nearest g) and sex. Numerous stations were sampled each year in the Gulf of Lions (i.e. inshore/offshore, west and east) to cover the complete area (Fig. 1) and to avoid bias of interannual differences due to spatial heterogeneity. In 2004, 2005 and 2014, zooplankton was sampled using a vertical WP2 net (200 $\mu \mathrm{m}$ mesh size) at each trawl station (4 stations in 2004 and 2005 and 10 in 2014). Zooplankton samples were stored in frozen sea water to be used in bulk for SIA. Using a combination of previously published data (Costalago et al. 2012, Le Bourg et al. 2015) and new samples that were analysed for this study, stable isotope values were available for June and July of 2004, 2005, 2008 and 2010 to 2014 (except for sprat in 2008 which was not sampled). Stomach content data were available in 2011 and 2012 for both anchovy and sardine (previously published data; $\mathrm{n}=118$ and 104 for sardine and anchovy, respectively; Le Bourg et al. 2015) as well as prior to population changes: in 2007 for sardine $(\mathrm{n}=$ 156; Costalago \& Palomera 2014) and in 1994 for anchovy ( $\mathrm{n}=50$, this study).

\section{SIA}

Fish isotope analyses were conducted on a ca. $1 \mathrm{~cm}^{3}$ piece of white muscle that had been kept frozen at $-80^{\circ} \mathrm{C}$ (Sweeting et al. 2005). Both fish white muscle and zooplankton samples were freeze-dried for $48 \mathrm{~h}$ and ground into a fine powder before being encapsulated in a tin cup and sent to the LIENSs laboratory (La Rochelle, France) for SIA analysis. An acidification step was necessary for zooplankton samples to remove any ${ }^{13} \mathrm{C}$-enriched carbonates (DeNiro \& Epstein 1978). A subsample was acidified with $1 \% \mathrm{HCl}_{\text {, }}$ rinsed with distilled water and dried to determine the $\delta^{13} \mathrm{C}$ ratio; an untreated subsample was used for $\delta^{15} \mathrm{~N}$ analysis. Three zooplankton replicates were performed from each sampled site for both $\delta^{13} \mathrm{C}$ and $\delta^{15} \mathrm{~N}$. A continuous-flow isotope ratio mass spectrometer (Delta V Advantage, Thermo Scientific) coupled to an elemental analyser (Flash EA1112, Thermo Scientific) was used to perform stable isotope measurements. Results were expressed in parts per thousand $(\%)$ relative to Vienna PeeDee Belemnite and atmos- 
pheric $\mathrm{N}_{2}$ for $\delta^{13} \mathrm{C}$ and $\delta^{15} \mathrm{~N}$, respectively, using the following equation:

$$
\delta X=\left[\left(R_{\text {sample }} / R_{\text {standard }}\right)-1\right] \times 10^{3}
$$

where $X$ is ${ }^{13} \mathrm{C}$ or ${ }^{15} \mathrm{~N}$ and $R$ is the isotope ratio ${ }^{13} \mathrm{C}:{ }^{12} \mathrm{C}$ or ${ }^{15} \mathrm{~N}:{ }^{14} \mathrm{~N}$. Replicate measurements of internal laboratory standards (acetanilide) indicated a precision of $0.2 \%$ for both $\delta^{13} \mathrm{C}$ and $\delta^{15} \mathrm{~N}$ values.

Variation in lipid content among fish species can introduce a bias in carbon stable isotope analyses (Post et al. 2007). Therefore, the potential effect of lipids on $\delta^{13} \mathrm{C}$ values of fish samples was corrected by applying the procedure of Post et al. (2007) when the $\mathrm{C}: \mathrm{N}$ ratio was $>3.5$ (which was mainly the case for sprat). Thus, the time and uncertainty due to lipid extraction were reduced. For all years, fish length ranges were kept similar (from $\sim 10$ to $15 \mathrm{~cm}$, Table 1) to avoid any bias due to ontogenetic changes.

\section{Stomach content analyses}

A similar protocol was applied to all analyses of stomach contents regardless of the year (see details in Costalago \& Palomera 2014, Le Bourg et al. 2015). Briefly, fish were frozen at $-20^{\circ} \mathrm{C}$ immediately after being caught to stop digestive processes. The gut was then removed and stored in $95 \%$ alcohol in the laboratory. Each stomach was carefully opened and all prey species were placed in a Petri dish and identified and quantified under a stereo microscope to the lowest possible taxonomic level, depending on the digestion state. Unidentified prey were excluded from the statistical analyses. A single difference in protocol occurred, as fish were analysed individually in all years except for sardines in 2007, for which fish

Table 1. Standard length and number of samples analysed for stable isotopes of anchovy Engraulis encrasicolus, sardine Sardina pilchardus and sprat Sprattus sprattus. NA: data not available

\begin{tabular}{|ccccccc|}
\hline \multirow{2}{*}{ Year } & \multicolumn{7}{c|}{ Mean \pm SD length $(\mathrm{mm})$} & & \\
\cline { 3 - 7 } & \multirow{2}{*}{ Anchovy } & $\mathrm{n}$ & Sardine & $\mathrm{n}$ & Sprat & $\mathrm{n}$ \\
\hline 2004 & $113 \pm 16$ & 65 & $131 \pm 22$ & 83 & $106 \pm 6$ & 14 \\
2005 & $121 \pm 15$ & 29 & $129 \pm 18$ & 25 & $114 \pm 8$ & 8 \\
2008 & $115 \pm 4$ & 15 & $136 \pm 4$ & 17 & $\mathrm{NA}$ & $\mathrm{NA}$ \\
2010 & $110 \pm 4$ & 32 & $100 \pm 5$ & 33 & $87 \pm 8$ & 32 \\
2011 & $103 \pm 19$ & 61 & $117 \pm 14$ & 51 & $96 \pm 8$ & 57 \\
2012 & $97 \pm 5$ & 36 & $111 \pm 13$ & 38 & $95 \pm 8$ & 50 \\
2013 & $108 \pm 17$ & 43 & $104 \pm 18$ & 38 & $103 \pm 8$ & 39 \\
2014 & $111 \pm 14$ & 49 & $121 \pm 15$ & 42 & $94 \pm 9$ & 36 \\
\hline
\end{tabular}

of a given station were pooled together, i.e. between 16 and 20 stomachs were pooled together. In that case, the associated sardine length corresponded to the mean length of all individuals from a given sample. Prey dry weight was derived from the literature (see Le Bourg et al. 2015).

Prey importance was assessed using the percentage of occurrence $(\% \mathrm{O}$, proportion of stomachs in which a given prey species was found), percentage in number $(\% \mathrm{~N}$, ratio between the number of a given prey species and the total number of prey), percentage in dry weight $(\% \mathrm{~W}$, ratio between the weight of a given prey species and the total weight of prey). These percentages were then combined to calculate the index of relative importance (IRI, Pinkas et al. 1971), which is necessary to compute the \%IRI; this allows an integrated comparison between dietary items of the same species (Hyslop 1980, Cortés 1997):

$$
\% \text { IRI }=\frac{\text { IRI }}{\sum_{a=1}^{n} \text { IRI }} \times 100
$$

where IRI $=\% \mathrm{O} \times(\% \mathrm{~N}+\% \mathrm{~W}), a$ is a specific prey category, and $\mathrm{n}$ is the number of prey species. Because of potential disparities in the names of species or groups of species between 1994 and 2011-2012, we carefully linked all prey names to current species names. Due to a lack of correspondence between periods, several species were not retained. However, these species/groups of species all had very low $\%$ IRI $(<0.2 \%)$, so that their absence would not significantly affect the computation of \%IRI and trophic niche width (see below).

The trophic niche width was measured for each period, using the exponential of Shannon's entropy, $N_{1}=\exp (H)$, where $H$ is the Shannon-Wiener diversity index calculated as $-\sum_{i=1}^{q} p_{i} \ln \left(p_{i}\right)$, where $i$ is a specific prey category, $q$ is the number of prey species, and $p_{i}$ is the proportion of IRI (Hill 1973, Medina et al. 2015).

\section{Data analyses}

\section{Determinants of isotopic values}

To investigate the potential effect of species, year, fish length, latitude, longitude and coastal/offshore gradient on $\delta^{13} \mathrm{C}$ and $\delta^{15} \mathrm{~N}$ values, we used the classification and regression tree (CART) approach of Breiman et al. (1984). Decision trees were built by recursively partitioning our dataset into increasingly homogeneous subgroups of isotope values. Each split is defined by a simple rule based on a single explana- 
tory variable, and each final group is characterized by its mean isotope values. Two separate CARTs were applied for fish $\delta^{13} \mathrm{C}$ and $\delta^{15} \mathrm{~N}$ values. As fewer stations and years were sampled for zooplankton, we only tested annual differences in $\delta^{13} \mathrm{C}$ and $\delta^{15} \mathrm{~N}$ to look for interannual variability $(2004,2005$ and 2014) using 1-way analyses of variance (ANOVA).

\section{Isotopic niches}

Standard ellipse areas corrected for small sample size (SEA $\mathrm{C}_{\mathrm{C}}$ Jackson et al. 2011), which define the isotopic niche space of $40 \%$ of typical individuals within the group based on bivariate normal distributions, were calculated as a measure of the mean core population isotopic niche in order to analyse resource partitioning among species over time. However, because both the shape and size of the area filled by the points influence this estimate, we first scaled isotope values as recommended by Cucherousset \& Villéger (2015) to obtain an informative assessment of isotopic overlap. Niche overlaps between the different species were then determined using SEA $_{c}$. Niche overlap varied between 0 (no overlap) and 1 (1 species is included in the other species' stable isotope space). In addition to niche overlap, the size of standard ellipses was also compared between species and between years for each species. To accomplish this, Bayesian standard ellipse areas $\left(\mathrm{SEA}_{B}\right)$ were calculated, which allowed for robust statistical comparisons. In addition, the probability of Bayesian ellipses, which were larger or smaller relative to the compared group, was computed ( $p$, the proportion of ellipses in 2011 that were lower than 2012, see Jackson et al. 2011 for more details). We considered 2 $\mathrm{SEA}_{\mathrm{B}}$ to be significantly different when more than $95 \%$ of the posterior estimates of one group were smaller than those of another group (Turner et al. 2010). Estimation via Bayesian inference allowed for robust comparisons among data sets comprising different sample sizes (Syväranta et al. 2013).

Temporal variation in stomach contents

To describe the temporal variations in stomach contents of anchovy and sardine, we applied a principal component analysis (PCA), which is a multivariate analysis of individuals' stomach contents as a function of prey using a correlation matrix. For each predator species, only prey constituting $>2 \%$ of $\%$ IRI in at least 1 of our data subsets were considered for the analysis, except for unidentified copepods. Empty stomachs were excluded from this analysis. To deal with different sampling strategies for sardine stomach contents between 2007 and 2011/2012, the 8 stations of 2007 (each representing between 16 and 20 individuals) were weighted by the number of corresponding individuals in the PCA analysis. The PCAs were performed on the dry weight $(\% \mathrm{~W})$ of the different prey ingested for each individual. Similar results were obtained when PCAs were performed on the proportion of frequency $(\% \mathrm{~N})$, showing the robustness of these results.

All statistical analyses were performed with $\mathrm{R}$ version 3.0.2. Values are indicated as mean \pm standard error (SE), and all statistical tests were performed at a significance level of 0.05 . All data were tested for normality and heteroscedasticity using KolmogorovSmirnov and Levene's tests.

\section{RESULTS}

\section{Factors influencing isotope values}

Fish size and nitrogen and carbon stable isotope ratios were determined for 330 anchovies, 327 sardines and 236 sprats (Table 1, Fig. 2). Using a CART analysis, $85 \%$ of the variability in the $\delta^{13} \mathrm{C}$ values were significantly explained by the variables year and species, whereas spatial locations of capture inside the Gulf of Lions (latitude and longitude), fish length and the coastal vs offshore gradient were not retained (Fig. 3a). The year variable had the greatest effect, and $\delta^{13} \mathrm{C}$ values were mainly split accordingly (Fig. 3a). First, the maxima for 2004 and 2005 were separated from all other years. In this small group, a secondary partition separated high $\delta^{13} \mathrm{C}$ sprat values from anchovy and sardine values. From all remaining years (2008 to 2014), the years 2010 and 2011 showed the most negative values, especially for sprat (Fig. 3a). Years 2008, 2012, 2013 and 2014 had intermediate $\delta^{13} \mathrm{C}$ values, with no differences among the 3 species studied. Between 2004 and 2014, the $\delta^{13} \mathrm{C}$ isotope values of all 3 species decreased progressively, but less for sardine and anchovy $(-2 \%)$ than for sprat (-3\%; Fig. 2).

According to the CART, $39 \%$ of the variability for the $\delta^{15} \mathrm{~N}$ signal was accounted for by year and species variables (Fig. 3b). In 2005 and 2011 to 2013, $\delta^{15} \mathrm{~N}$ values were lower for anchovy and sprat in comparison to sardine (Fig. 3b). In contrast, during all other years (2004, 2008, 2010 and 2014), sardine and sprat had more similar $\delta^{15} \mathrm{~N}$ values than anchovy. 

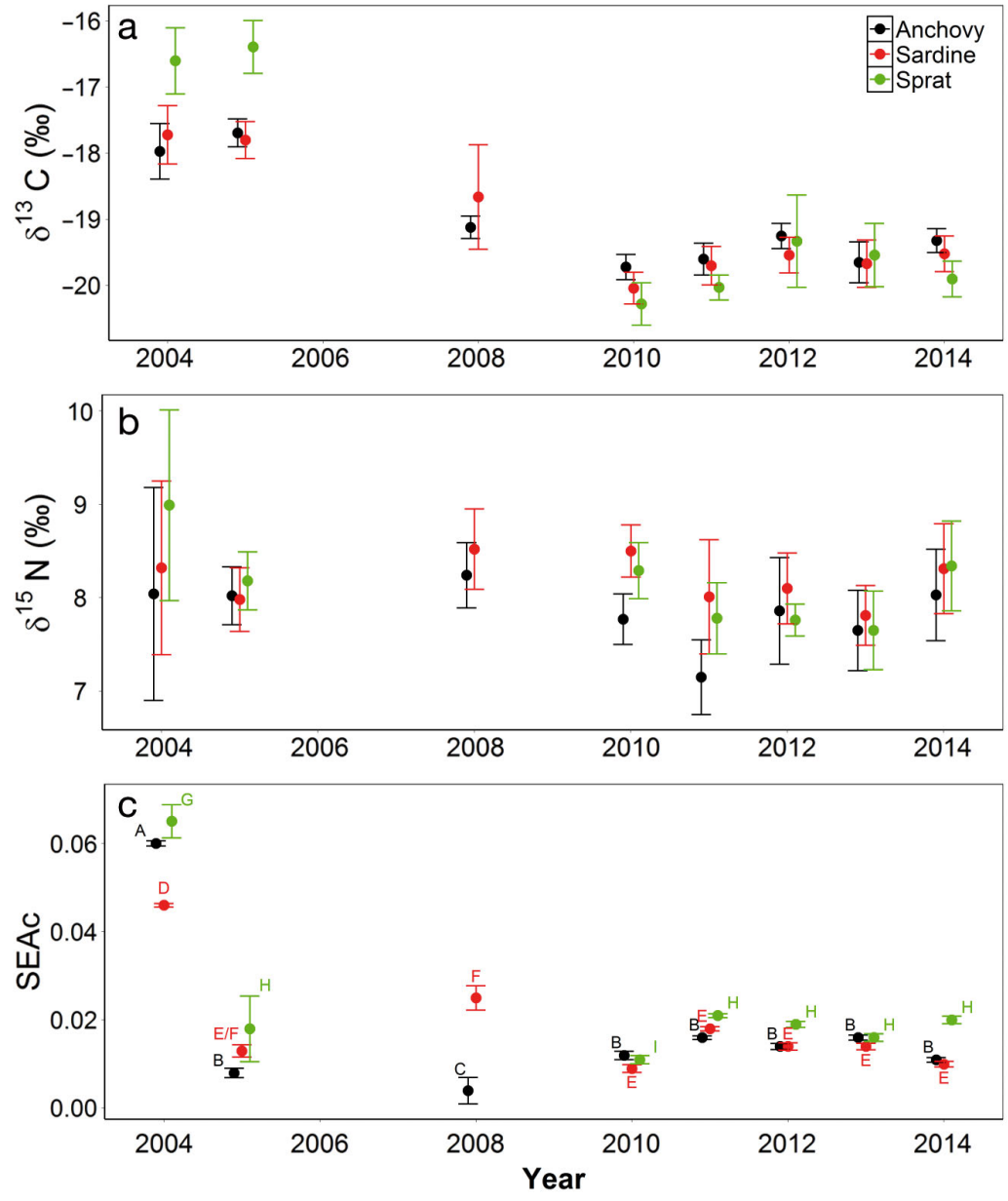

Fig. 2. Summary of (a) $\delta^{13} \mathrm{C}$ and (b) $\delta^{15} \mathrm{~N}$ values (mean $\pm \mathrm{SD}$, in \%o), and (c) trophic niche size of sardine Sardina pilchardus, anchovy Engraulis encrasicolus and sprat Sprattus sprattus over time in the Gulf of Lions. SEA : standard ellipse area corrected for small sample sizes, indicated in $\%^{2}$. The Bayesian area estimates of the standard ellipse metrics $\left(\mathrm{SEA}_{B}\right)$ that present significant differences between years for each species are indicated by different superscripts (A-C for anchovy, D-F for sardine and G-I for sprat)

Only in anchovy in certain years did other variables affect isotope values. Anchovy values in 2004, 2008, 2010 and 2014 also depended on the sampling location, in particular the longitude, with lower values in the east. Moreover, in the western part during those years, anchovy $\delta^{15} \mathrm{~N}$ values increased with size (Fig. 3b). However, even if year was significant in the CART analysis (Fig. 3b), during our study period only a slight difference in trophic levels was observed for any species $\left(\delta^{15} \mathrm{~N}\right.$ range), with no clear temporal trend (Fig. 2).

Similarly to fish, the $\delta^{13} \mathrm{C}$ values of the bulk of zooplankton were higher in 2004 and 2005 in comparison to 2014 (ANOVA, $p<0.001$ ), while $\delta^{15} \mathrm{~N}$ values remained stable over time (ANOVA, $p>0.05$; see Fig. A1 in the Appendix).

\section{Temporal changes in isotopic niche overlap}

Fig. 4 displays the Bayesian ellipse areas $\left(\mathrm{SEA}_{\mathrm{C}}\right)$ that represent the isotopic niche of the 3 small pelagic species in a scaled isotopic niche space. Two patterns were observed: firstly, sprat was segregated from sardine and anchovy during the 2 earliest years (2004 and 2005, Fig. 4); second, the overlap of the sprat isotopic niche on that of sardine was present until 2014 (Table 2). Sprat also overlapped strongly with anchovy in 2012 and 2013, but no clear temporal trend was evidenced (Table 2). In contrast, the trophic niche overlap of sardine and anchovy was high in 2004 and 2005 (Table 2). In 2008, the total anchovy niche even fell within that of sardine (100\% overlap). However, during the subsequent years (2010-2014), overlap was much lower except for 2013 (at least halved compared to before 2010, Table 2). For each species, the isotopic location of the $\mathrm{SEA}_{\mathrm{c}}$ differed among years (Fig. 4).

\section{Temporal changes in isotopic niche width}

The niche width of the 3 species varied notably between years (Fig. 2). The anchovy isotopic niche width decreased between 2004 and $2008\left(\mathrm{SEA}_{\mathrm{B}}: \mathrm{p}<0.001\right)$ and then increased to remain steady at middle values ( $\mathrm{SEA}_{\mathrm{B}}$ : $\mathrm{p}>0.05$, Fig. 2). The sardine isotopic niche width also decreased between 2004 and $2005\left(\mathrm{SEA}_{\mathrm{B}}: \mathrm{p}<0.001\right)$, but increased between 2005 and $2008\left(\mathrm{SEA}_{B}\right.$ : $\left.\mathrm{p}<0.01\right)$ and then decreased again in $2010\left(\mathrm{SEA}_{B}: \mathrm{p}<0.01\right)$ and finally remained steady until $2014\left(\mathrm{SEA}_{\mathrm{B}}: \mathrm{p}>0.05\right.$, Fig. 2). The isotopic niche width of sprat decreased between 2004 and $2010\left(\mathrm{SEA}_{\mathrm{B}}: \mathrm{p}<0.01\right)$ and subsequently increased and stabilized from 2011 to $2014\left(\mathrm{SEA}_{\mathrm{B}}\right.$ : p > 0.05, Fig. 2). In 2010 and 2013, the $\mathrm{SEA}_{B}$ width was similar between all 3 species ( $\mathrm{SEA}_{B}: \mathrm{p}>0.05$, Fig. 2), whereas during the years 2004, 2005, 2011, 2012 and 2014, sprat always had a larger $\mathrm{SEA}_{B}$ than sardine and anchovy ( $\mathrm{SEA}_{B}$ : $\mathrm{p}<0.05$, Fig. 2). In 2008, when only 2 species were available, sardine $\mathrm{SEA}_{B}$ was significantly larger than that of anchovy $\left(\mathrm{SEA}_{\mathrm{B}}\right.$ : $\mathrm{p}<0.001$ ). 

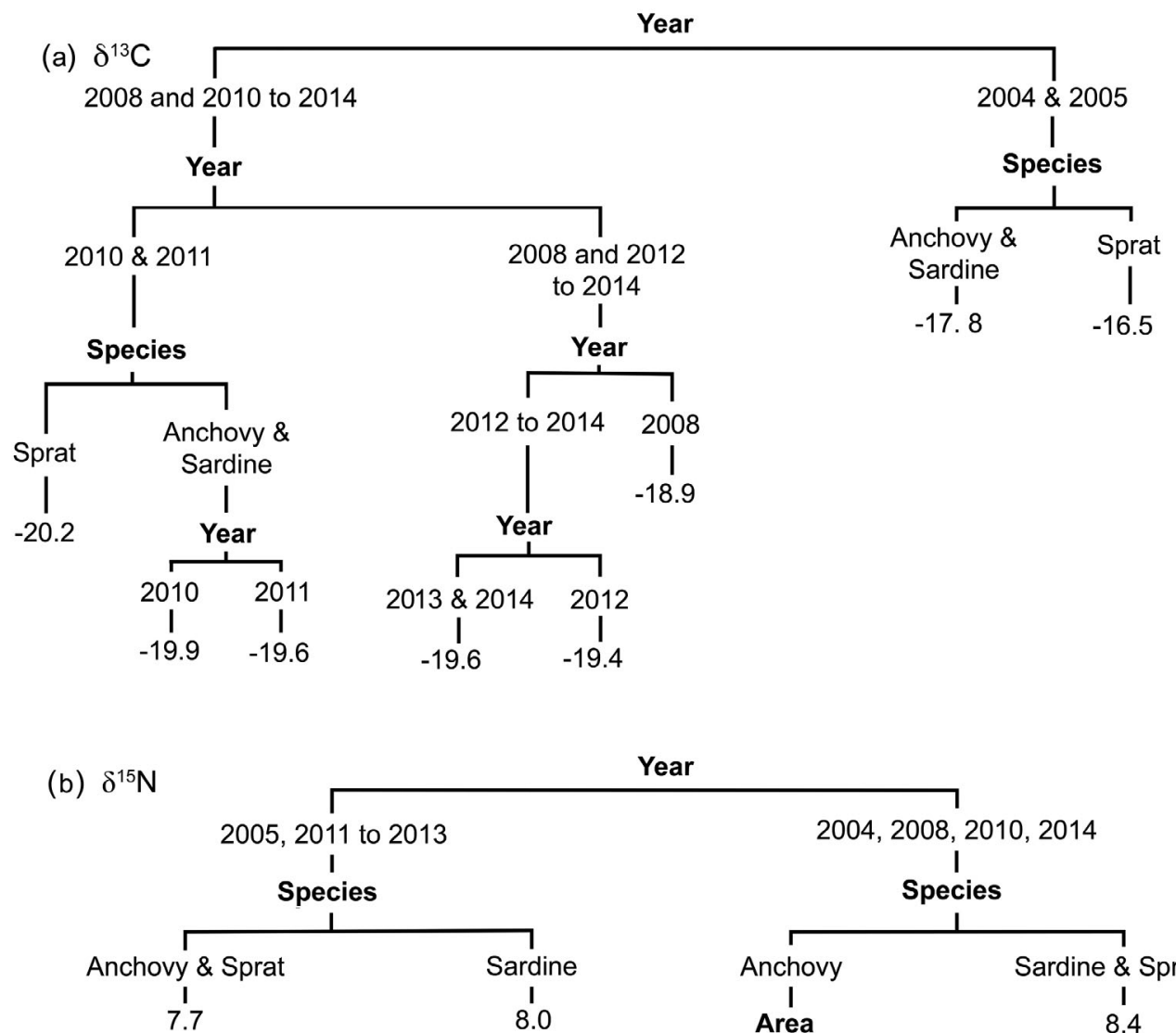

Fig. 3. Classification and regression tree assessing the importance of year, species, fish length, latitude, longitude and coastal/offshore gradient on (a) $\delta^{13} \mathrm{C}$ values and (b) $\delta^{15} \mathrm{~N}$ values. Trees are split off on the values of 1 covariate at a time such that the overall variance in the dependent variable is minimized at each split. Terminal nodes indicate the value of $\delta^{13} \mathrm{C}$ or $\delta^{15} \mathrm{~N}$ assigned to the node

Year

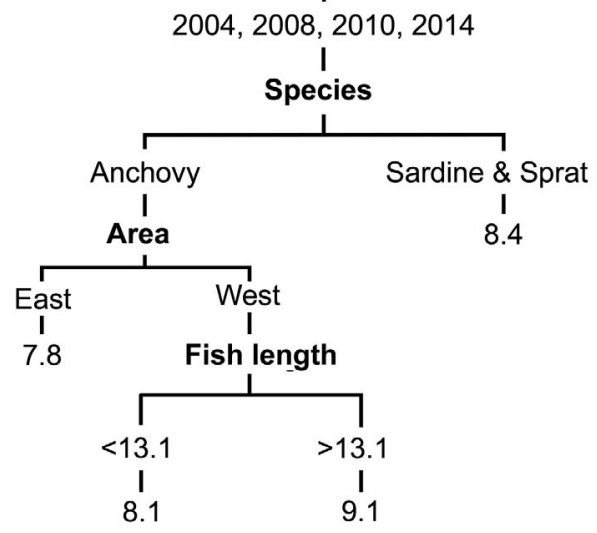

Table 2. Standard ellipse overlaps for each combination of species. The values represent the percentage of overlap between the standard ellipse areas in the scaled stable isotope space. Each number in the cell refers to the percentage of overlap of the area of the species indicated first (e.g. $68 \%$ is the percentage of ellipses of sardine Sardina pilchardus that overlapped with ellipses of anchovy Engraulis encrasicolus, $52 \%$ is the percentage of ellipses of anchovy that overlapped with ellipses of sardine). NA: not applicable

\begin{tabular}{|ccccccc|}
\hline Year & $\begin{array}{c}\text { Sardinel } \\
\text { anchovy }\end{array}$ & $\begin{array}{c}\text { Anchovyl } \\
\text { sardine }\end{array}$ & $\begin{array}{c}\text { Anchovyl } \\
\text { sprat }\end{array}$ & $\begin{array}{c}\text { Spratl } \\
\text { anchovy }\end{array}$ & $\begin{array}{c}\text { Sardinel } \\
\text { sprat }\end{array}$ & $\begin{array}{c}\text { Spratl } \\
\text { sardine }\end{array}$ \\
\hline 2004 & 68 & 52 & 0 & 0 & 0 & 0 \\
2005 & 58 & 89 & 0 & 0 & 0 & 0 \\
2008 & 100 & 15 & NA & NA & NA & NA \\
2010 & 0 & 0 & 0 & 0 & 50 & 41 \\
2011 & 12 & 14 & 8 & 6 & 41 & 35 \\
2012 & 14 & 13 & 69 & 52 & 43 & 30 \\
2013 & 69 & 63 & 65 & 65 & 54 & 49 \\
2014 & 32 & 27 & 9 & 5 & 70 & 32 \\
\hline
\end{tabular}

\section{Size, area and temporal variations in diet composition}

The diet of sardine and anchovy was mainly zooplanktivorous, with some traces of phytoplankton consumption (diatoms) in 2011/2012 for both species (see Tables 3 \& 4). The anchovy diet in 1994 was characterized by the dominance of Acartia clausi (18.23\% IRI), Microsetella spp. (13.52\% IRI), individuals belonging to the genera Clausocalanus and Paracalanus (hereafter referred to as Clauso/Paracalanidae; $13.22 \%$ IRI), Oncaea spp. (12.67\% IRI) and Euphausiacaea larvae (7.31\% IRI) (Table 3). Copepods also dominated the anchovy diet in 2011/2012, but anchovy fed almost exclusively on 2 gen- 

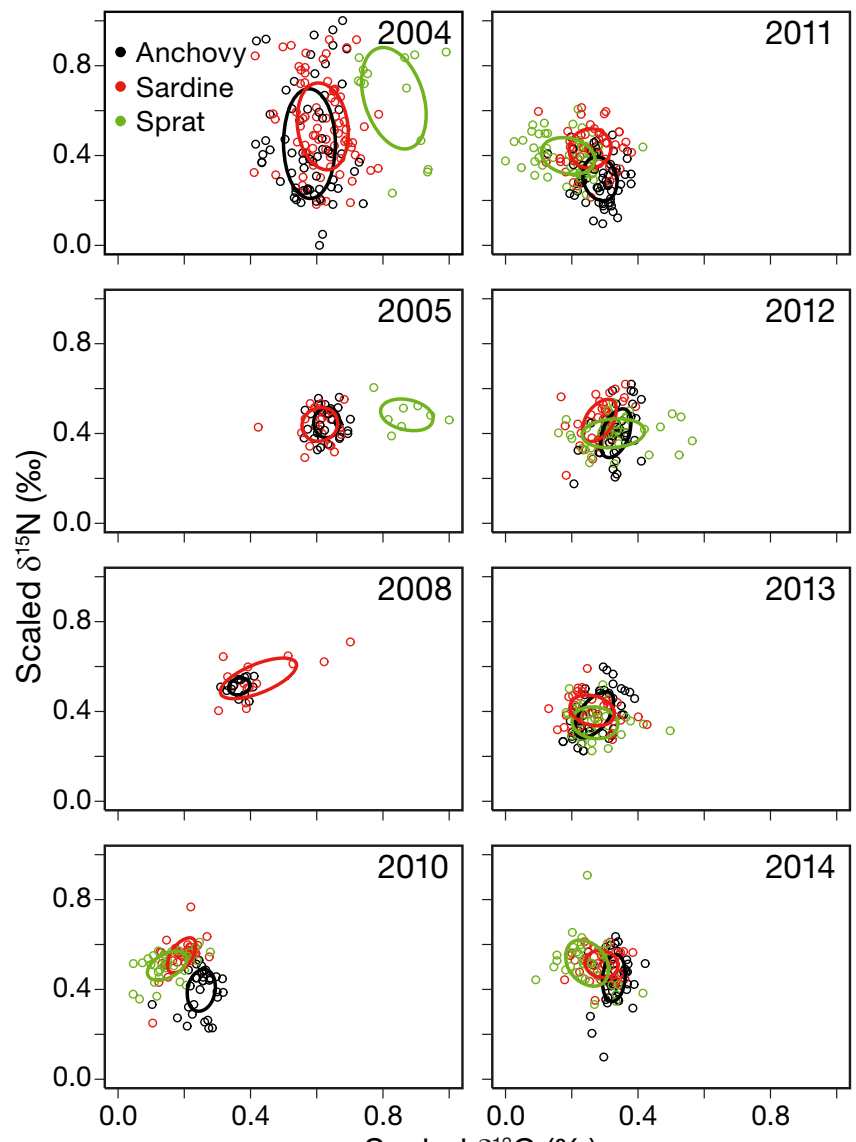

Scaled $\delta^{13} \mathrm{C}(\%)$

Fig. 4. Species scaled isotopic niche space between 2004 and 2014, represented by solid bold lines based on the area of the standard ellipses corrected for small sample sizes (SEAc). Stable carbon and nitrogen isotope values are from the muscle of adult anchovy Engraulis encrasicolus, sardine Sardina pilchardus and sprat Sprattus sprattus

era: Microsetella spp. (34.78\% IRI) and Oncaea spp. (27.52\% IRI). In 2007, sardine diet was composed of copepods (60.31\% IRI, mainly Euterpina acutifrons, Microsetella spp. and Temora stylifera) and cladocerans $(31.48 \%$ IRI). In contrast, cladocerans were almost absent in 2011/2012, while Microsetella spp. (29.34\% IRI), Oncaea spp. (24.55\% IRI) and Corycaeus spp. (21.64\% IRI) dominated the sardine diet (Table 4). For both sardine and anchovy, we also found a strong increase in the proportion of Corycaeidae during years 2011 and 2012.

The trophic niche width, measured with the exponential of Shannon's entropy, was highest in the earliest period studied for both species (10.84 in 1994 versus 5.57 in 2011/2012 for anchovy, Table 3; and 8.54 in 2007 versus 6.46 in 2011/2012 for sardine, Table 4).
In the PCA performed on the dry weight $(\% \mathrm{~W})$ of the different prey of anchovy, the first (Dim1) and second (Dim2) component represented 35\% and $25 \%$ of the total variance, respectively (Fig. 5). Dim1 represented a gradient whereby Oncaea spp. was opposed mainly to Acartia clausi and Clauso/Paracalanidae species. Dim2 represented a gradient with Microsetella spp. opposed to A. clausi and Clauso/ Paracalanidae species in anchovy diet. The majority of anchovy from 1994 had negative values on both axes, while the majority of anchovy from 2011/2012 had positive values. Thus, we deduced an increasing proportion in dry weight of Microsetella spp. and Oncaea spp. and a decreasing proportion of A. clausi and Clauso/Paracalanidae species in the anchovy diet from 1994 to 2011/2012 (Fig. 5). In the PCA carried out on the sardine data, Dim1 and Dim2 represented $44 \%$ and $18 \%$ of the total variance, respectively (Fig. 6). Microsetella spp. was opposed to Oncaea spp., Corycaeus spp. and cladocerans on the Dim1 axis, while the second axis showed a clear separation between the cladocerans and other prey species. The 2 time periods were opposed on the second axis, reflecting a decreasing gradient of cladocerans and an increasing proportion of Oncaea spp., Corycaeus spp. and Microsetella spp. in the sardine diet from 2007 to 2011/2012. Fish length (4 length classes of $1.5 \mathrm{~cm}$ from 10 to $16 \mathrm{~cm}$ ) as well as sampling area ( 3 areas; west, central and east) were plotted on the PCA, but both factors displayed no trend.

\section{DISCUSSION}

Data availability does not allow us to describe the trophic ecology over the last $20 \mathrm{yr}$, but we can contrast the present situation to data collected before the drastic changes in demography occurred. The comparison of small pelagic trophic data (1) showed a wider isotopic niche in sprat compared to sardine and anchovy, (2) tended to confirm the hypothesis of changes in the anchovy and sardine diets, and (3) suggested a recent increase in the trophic overlap between the different small pelagic fish species of the Gulf of Lions.

Using SIA and isotope-derived metrics to study interspecific trophic differences, we showed that sprat had a larger isotopic niche width (in 2004, 2005, 2011, 2012 and 2014) than sardine and anchovy or at least equivalent (in 2010 and 2013), mainly due to the broad range of $\delta^{13} \mathrm{C}$. Assuming that the wider sprat isotopic niche reflects higher variability in individual diets (Matthews \& Mazumder 2004), sprat intraspeci- 
Table 3. Summary of stomach content analysis for anchovy Engraulis encrasicolus. $\% \mathrm{~N}$ : percent by number; \%W: percent estimated dry weight; \%O: percent frequency of occurrence; \%IRI: percent index of relative importance; $\operatorname{Exp}(H)$ : trophic niche width based on stomach content analysis. Individuals belonging to the genera Clausocalanus and Paracalanus are grouped as 'Clauso-Paracalanidae'. -: taxon not found

\begin{tabular}{|c|c|c|c|c|c|c|c|c|}
\hline \multirow[t]{2}{*}{ Prey type } & \multicolumn{4}{|c|}{$-1994-\ldots$} & \multicolumn{4}{|c|}{-2011 and 2012} \\
\hline & $\% \mathrm{~N}$ & $\% \mathrm{~W}$ & $\% \mathrm{O}$ & $\%$ IRI & $\% \mathrm{~N}$ & $\% \mathrm{~W}$ & $\% \mathrm{O}$ & $\%$ IRI \\
\hline \multicolumn{9}{|l|}{ Crustacea } \\
\hline \multicolumn{9}{|l|}{ Copepods } \\
\hline Acartia clausi & 6.60 & 30.36 & 57.90 & 18.23 & 2.64 & 7.98 & 18.27 & 2.29 \\
\hline Clauso-Paracalanidae & 13.54 & 19.49 & 52.63 & 13.22 & 6.36 & 3.68 & 15.38 & 1.83 \\
\hline Centropages typicus & 9.76 & 4.82 & 50 & 6.21 & 3.60 & 3.64 & 21.15 & 1.81 \\
\hline Corycaeus spp. & 1.72 & 2.05 & 55.26 & 1.78 & 4.45 & 23.81 & 43.27 & 14.46 \\
\hline Clytemnestra & 0.02 & $<0.01$ & 2.63 & $<0.01$ & 0.08 & $<0.01$ & 1.92 & $<0.01$ \\
\hline Candacia spp. & 4.00 & 8.15 & 44.74 & 4.63 & 0.90 & 1.10 & 10.58 & 0.25 \\
\hline Oithona spp. & 1.48 & 0.07 & 42.11 & 0.55 & 0.12 & $<0.01$ & 5.77 & $<0.01$ \\
\hline Oncaea spp. & 15.30 & 0.39 & 94.74 & 12.67 & 20.15 & 15.43 & 65.38 & 27.52 \\
\hline Microsetella spp. & 16.08 & 0.22 & 97.37 & 13.52 & 26.38 & 13.34 & 74.04 & 34.78 \\
\hline Euterpina acutifrons & 1.25 & 0.36 & 94.74 & 1.30 & 2.01 & 0.13 & 36.54 & 0.89 \\
\hline Temora stylifera & 1.22 & 0.41 & 42.11 & 0.59 & 0.02 & $<0.01$ & 0.96 & $<0.01$ \\
\hline Unidentified copepods & 23.26 & 0.78 & 71.05 & 14.55 & 15.36 & 18.69 & 32.69 & 13.16 \\
\hline Cladoceran & 2.79 & 5.36 & 73.68 & 3.37 & 0.33 & $<0.01$ & 9.62 & 0.04 \\
\hline Ostracod & 0.29 & 0.03 & 44.73 & 0.08 & 1.29 & 0.29 & 22.12 & 0.41 \\
\hline \multicolumn{9}{|l|}{ Tunicata } \\
\hline Appendicularia & - & - & - & - & 0.12 & $<0.01$ & 0.96 & $<0.01$ \\
\hline \multicolumn{9}{|l|}{ Protists } \\
\hline Diatoms & - & - & - & - & 9.21 & 9.60 & 3.85 & 0.86 \\
\hline \multicolumn{9}{|l|}{ Chaetognatha } \\
\hline Chaetognatha & 0.05 & 0.01 & 2.63 & $<0.01$ & - & - & - & - \\
\hline \multicolumn{9}{|l|}{ Larvae } \\
\hline \multicolumn{9}{|l|}{ Crustacea } \\
\hline Euphausiacea & 0.21 & 26.96 & 31.57 & 7.31 & 2.34 & 3.31 & 7.69 & 0.45 \\
\hline Decapoda & 0.35 & 0.19 & 34.21 & 0.16 & 1.89 & 1.47 & 11.54 & 0.46 \\
\hline \multicolumn{9}{|l|}{ Mollusca } \\
\hline Gastropodae & $<0.01$ & 0.03 & 5.26 & $<0.01$ & 1.98 & 0.04 & 10.58 & 0.25 \\
\hline Bivalve & 0.02 & 0.30 & 42.11 & 0.11 & 1.68 & 0.29 & 23.08 & 0.54 \\
\hline \multicolumn{9}{|l|}{ Eggs } \\
\hline Anchovy & 0.15 & 0.09 & 47.37 & 0.10 & 1.1 & 0.49 & 16.35 & 0.31 \\
\hline Other fish & 0.24 & 0.42 & 50 & 0.28 & 0.14 & $<0.01$ & 2.88 & $<0.01$ \\
\hline & & $\operatorname{Exp}(H)$ & $=10.8$ & & & $\operatorname{Exp}(I$ & $H)=5.5$ & \\
\hline
\end{tabular}

fic trophic competition may be lower than those of other species. Additionally, stomach content analyses tended to indicate a slightly more diversified sprat diet (Le Bourg et al. 2015). These results are particularly interesting from a population dynamics viewpoint. Indeed, sprat biomass has considerably increased since 2008, while the ratio of biomass: abundance of both sardine and anchovy has considerably declined (GFCM 2015). Previous studies have shown that those changes were mainly driven by reduced growth, age truncation and condition, and bot- tom-up processes were the most likely drivers (Van Beveren et al. 2014). Being a generalist feeder with low intraspecific food competition might thus have conferred important advantages to sprat over sardine and anchovy, especially to adapt to environmental changes. This might also explain why sprat body condition was more stable, while sardine and anchovy condition exhibited stronger ups and downs, possibly in reaction to prey variability (Van Beveren et al. 2014).

This study also depicts a considerable reduction in both sardine and anchovy isotopic niches through time. The carbon isotopic composition of fish muscle is mainly related to the ingested prey items (Hobson 1999). As previously stated, strong changes in $\delta^{13} \mathrm{C}$ values of small pelagic fish and zooplankton were observed over time. Differences between years in fish stable isotope values may be due to inter-annual differences in the planktonic community and/or the organic matter, the latter being at the basis of the food web. The Gulf of Lions is further known as a highly variable area in water circulation, productivity and stable isotope ratios of the plankton community (André et al. 2005, Espinasse et al. 2014), which could add variability in fish isotopic signature. Yet, similarly to previous findings obtained with a different methodology (e.g. fatty acid profiles, Pethybridge et al. 2014), we showed that isotopic values did not differ between sampling areas except for $\delta^{15} \mathrm{~N}$ in anchovy during some years, underlining the weak influence of the sampling area on the isotopic values at the scale of the present study. This allows us to reasonably assume that differences were not due to sampling bias, even if the sampling locations varied from year to year. A reduction of the anchovy isotopic niche was observed 
Table 4. Summary of stomach content analysis for sardine Sardina pilchardus. Abbreviations as in Table 3

\begin{tabular}{|c|c|c|c|c|c|c|c|c|}
\hline \multirow[t]{2}{*}{ Prey type } & \multicolumn{4}{|c|}{2007} & \multicolumn{4}{|c|}{2011 and 2012} \\
\hline & $\% \mathrm{~N}$ & $\% \mathrm{~W}$ & $\% \mathrm{O}$ & \%IRI & $\% \mathrm{~N}$ & $\% \mathrm{~W}$ & $\% \mathrm{O}$ & \%IRI \\
\hline \multicolumn{9}{|l|}{ Crustacea } \\
\hline \multicolumn{9}{|l|}{ Copepods } \\
\hline Acartia clausi & - & - & - & - & 3.58 & 8.14 & 0.12 & 1.74 \\
\hline Clauso-Paracalanidae & 3.26 & 6.78 & 62.50 & 4.36 & 7.07 & 5.05 & 0.41 & 5.95 \\
\hline Centropages typicus & - & - & - & - & 1.51 & 1.55 & 0.13 & 0.49 \\
\hline Corycaeus spp. & 4.09 & 4.11 & 75.00 & 4.28 & 8.61 & 30.10 & 0.46 & 21.64 \\
\hline Clytemnestra & - & - & - & - & 0.43 & 0.16 & 0.03 & 0.02 \\
\hline Candacia spp. & 0.16 & 18.27 & 12.50 & 1.60 & 0.13 & 1.04 & 0.03 & 0.04 \\
\hline Oithona spp. & - & - & - & - & 0.16 & 0.04 & 0.04 & $<0.01$ \\
\hline Oncaea spp. & 11.58 & 0.61 & 100 & 8.48 & 17.61 & 12.27 & 0.68 & 24.55 \\
\hline Microsetella spp. & 6.31 & 11.11 & 87.50 & 10.60 & 24.65 & 10.09 & 0.70 & 29.34 \\
\hline Euterpina acutifrons & 3.82 & 19.27 & 62.50 & 10.03 & 9.12 & 4.43 & 0.36 & 5.87 \\
\hline Temora stylifera & 2.01 & 30.95 & 50.00 & 11.46 & - & - & - & - \\
\hline Unidentified copepods & 10.73 & 2.92 & 100.00 & 9.50 & 9.43 & 6.06 & 0.25 & 4.77 \\
\hline Cladoceran & 43.64 & 1.63 & 100 & 31.48 & 1.08 & 0.70 & 0.11 & 0.24 \\
\hline Ostracod & - & - & - & - & 1.09 & 1.55 & 0.12 & 0.39 \\
\hline \multicolumn{9}{|l|}{ Tunicata } \\
\hline Appendicularia & 0.08 & 0.06 & 12.50 & 0.02 & - & - & - & - \\
\hline \multicolumn{9}{|l|}{ Protists } \\
\hline Diatoms & 8.39 & 0.79 & 75.00 & 4.79 & 5.85 & 9.00 & 0.11 & 2.03 \\
\hline \multicolumn{9}{|l|}{ Chaetognatha } \\
\hline Chaetognatha & - & - & - & - & $<0.01$ & $<0.01$ & $<0.01$ & $<0.01$ \\
\hline \multicolumn{9}{|l|}{ Larvae } \\
\hline \multicolumn{9}{|l|}{ Crustacea } \\
\hline Euphausiacea & - & - & - & - & - & - & - & - \\
\hline Decapoda & 0.54 & 2.63 & 37.5 & 0.83 & 0.09 & 0.76 & 0.05 & 0.05 \\
\hline \multicolumn{9}{|l|}{ Mollusca } \\
\hline Gastropodae & - & - & - & - & 0.12 & $<0.01$ & 0.02 & $<0.01$ \\
\hline Bivalve & 1.29 & 0.19 & 50.00 & 0.51 & 1.09 & 1.04 & 0.09 & 0.24 \\
\hline \multicolumn{9}{|l|}{ Eggs } \\
\hline Anchovy & - & - & - & - & 5.40 & 6.87 & 0.11 & 1.68 \\
\hline \multirow[t]{2}{*}{ Other fish } & - & - & - & - & 2.80 & 0.83 & 0.21 & 0.91 \\
\hline & \multicolumn{4}{|c|}{$\operatorname{Exp}(H)=8.54$} & \multicolumn{4}{|c|}{$\operatorname{Exp}(H)=6.46$} \\
\hline
\end{tabular}

between 2004 and 2013, although the largest shrinkage occurred between 2004 and 2005. Nevertheless, this considerable change in isotopic niche area between the 2 years has to be considered with caution, due to the lower sampling size in 2005 in comparison to 2004, which reduces the precision of the estimated mean niche width (see Syväranta et al. 2013). The largest reduction in sardine isotopic niche was observed between 2008 and 2013, concomitantly with the decrease in sardine size, condition and biomass.

Moreover, stomach contents also confirmed a significant reduction in the trophic niche width of both anchovy and sardine $(25 \%$ and almost $50 \%$, respec- tively). Specifically, both species displayed a much narrower diet during recent years (2011/2012) compared to previous time periods (1994 or 2007). This might have resulted from a decrease in the availability of certain prey species, downplaying their role in the diet of the small pelagics, as indicated by temporal differences in composition and size range of consumed prey. The sampling methodology was kept as consistent as possible during the study, especially in terms of season, fishing gear and daylight time. Hence, changes could only be related to variables such as year, area and fish size. However, no size class or sampling area effects were detected during the analyses, so that observed changes are likely to be due to a year effect. For adult anchovy and sardine, copepods were, as in most other studies in the Mediterranean (see Tudela \& Palomera 1997, Borme et al. 2009, Nikolioudakis et al. 2012), by far the most important prey item, regardless of the year. However, there was a prey size reduction between both periods. In 1994, large copepods (size $>1 \mathrm{~mm}$, Acartia spp., Candacia spp., Clauso/Paracalanus spp. and Centropages typicus), attained almost $50 \%$ of the \%IRI and $65 \%$ in relative dry weight (\%W). This contrasted with 2011/2012, when they represented barely more than $5 \%$ of the IRI and $15 \%$ in \%W (Le Bourg et al. 2015). Large copepods in the anchovy diet were replaced in 2011/ 2012 by small copepods species (size $<1 \mathrm{~mm}$, such as Coryceidae, Microsetella spp. and Oncaea spp.), which increased three-fold. The proportion of small and large copepods in 1994 was in agreement with another study from 1995 and 1996, performed in the same area and during the same period (Plounevez \& Champalbert 2000). Marked changes between 1994 and 2011/2012 in the anchovy diet also concerned other prey groups, such as cladocerans that became 


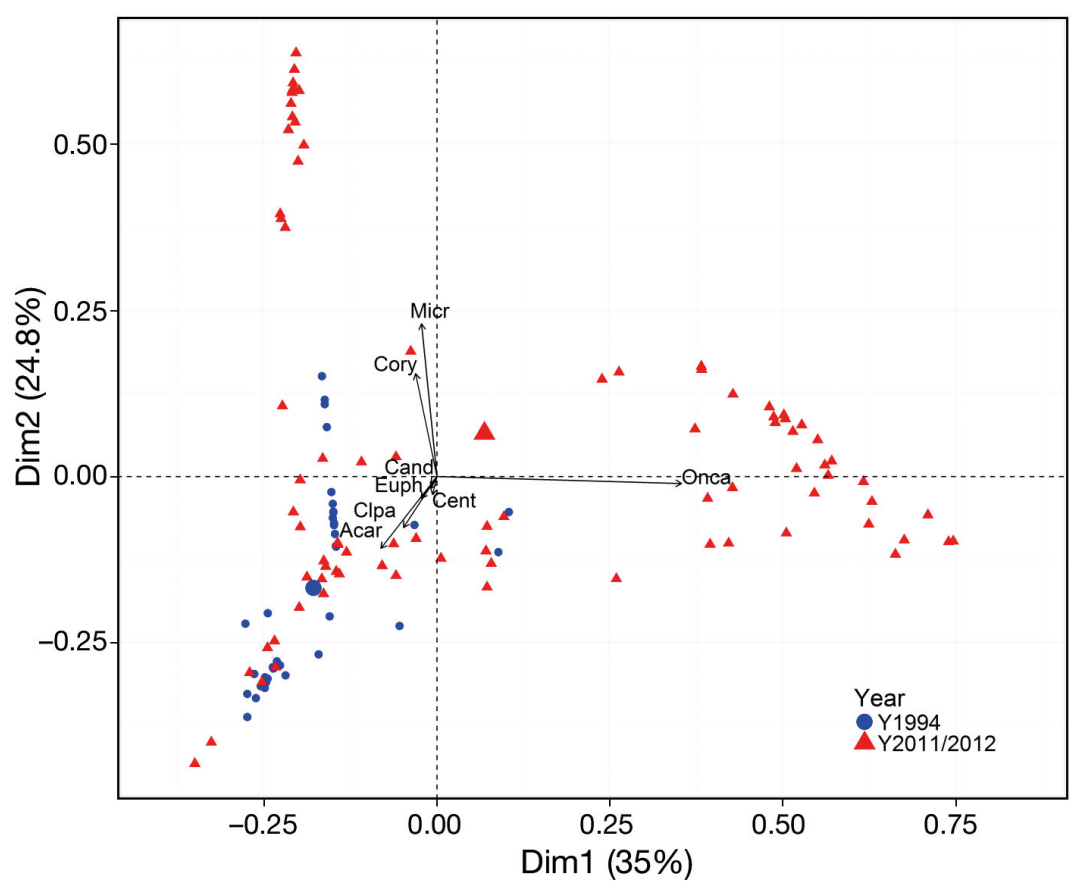

Fig. 5. Principal component analysis of the dry weight percentage of the main anchovy prey in the Gulf of Lions. Cory: Corycaeus spp.; Micr: Microsetella spp.; Clpa: Clauso-Paracalanidae (individuals belonging to the genera Clausocalanus and Paracalanus); Onca: Oncaea spp.; Cand: Candacia spp.; Acar: Acartia clausi; Euph: Euphausiacae; Cent: Centropages typicus. Barycentres of the years (Y) are added as supplementary variables

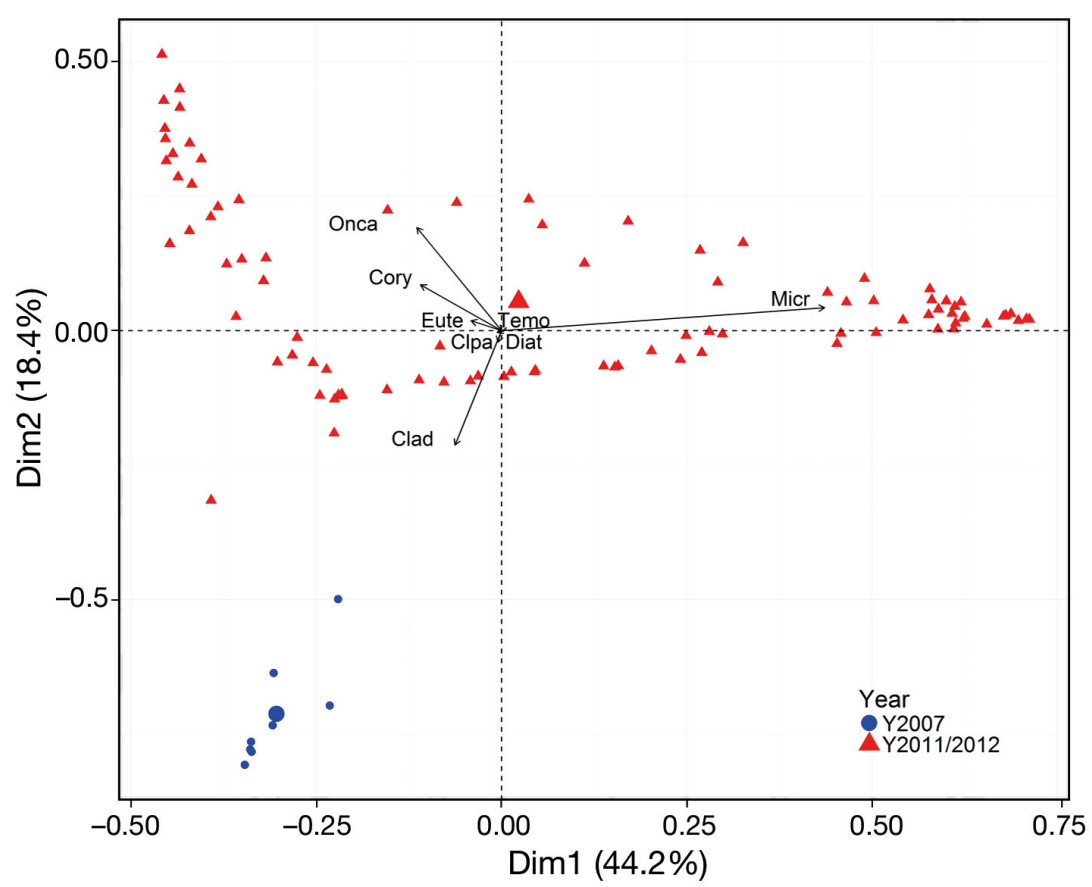

Fig. 6. Principal component analysis of the dry weight percentage of the main sardine prey in the Gulf of Lions. Clad: cladoceran; Temo: Temora stylifera; Cory: Corycaeus spp.; Micr: Microsetella spp; Eute: Euterpina acutifrons; Diat: Diatoms; Clpa: Clauso-Paracalanidae; Onca: Oncaea spp. Barycentres of the years (Y) are added as supplementary variables practically absent in recent years and larvae (mainly Euphausiacea) that also decreased, while diatoms appeared. The decrease of large Euphausiacea larvae, recognized as important anchovy prey in other areas such as the Humboldt Current (Ayón et al. 2011), might have accentuated the deficiency in large prey species.

Similarly, small copepods dominated the sardine diet in recent years, while cladocerans were the dominant prey in 2007. Assuming that larger copepods have a higher energy content (Dumont et al. 1975, Vijverberg \& Frank 1976, Zarubin et al. 2014), current nutritional conditions of anchovy and sardine might have thus strongly decreased compared to pre-2008, potentially explaining the strong demographic changes observed in both species after 2008. Furthermore, fish were sampled in July, when adults need to accumulate their fat supply to survive the next winter (Wiegand 1996, Sánchez Gómez 2013). Therefore, the lack of large copepods in their stomachs could reflect difficulties in building sufficient fat reserves to survive an energetically demanding winter, especially for sardines which reproduce at that moment. This might thus explain the apparent high adult mortality rate detected for sardine (less pronounced for anchovy, Van Beveren et al. 2014). However, in order to better understand the impact of the changes in sardine and anchovy diet, a detailed investigation of zooplankton variations in terms of quantity/quality and fish energetics would be required.

Nonetheless, considering the usual importance of large copepods in the diet of anchovy and sardine, these changes probably reflect a potential decrease in their availability, which might result either from an increase in competition between fish species or a decrease in abundance of large copepods. First, the increase in sprat abundance and biomass might have 
drawn more intensive interspecific competition. Indeed, all 3 species have been shown to inhabit the same areas and to spatially co-occur in the Gulf of Lions, except for some deeper grounds where only anchovy occurs (Saraux et al. 2014).

The hypothesis of increased interspecific competition during the last decade is supported by the changes in the degree of overlap and segregation in the isotopic niches of the fish species. There was clear isotopic niche segregation between sprat and the 2 other species in 2004 and 2005, indicating that sprat could have exploited different species groups from anchovy and sardine during these still prosperous years. However, sprat diet has overlapped significantly with anchovy and/or sardine diet since 2010. Conversely, the overlap between anchovy and sardine was strong in 2004, 2005 and 2008, but was nearly inexistent in 2010, 2011, 2012 and 2014. These SIA are in accordance with stomach content analyses, which also provided evidence for potentially strong competition between sprat, sardine and anchovy (Le Bourg et al. 2015). Thus, this study underlines the importance of new food sharing in the context of the recent increase in the sprat population. The special case of 2013 might have been caused by very limited food resources (quantitatively or/and qualitatively), forcing the 3 species to highly exploit prey species with similar stable isotope ratios (possibly similar prey species).

Second, beyond prey size spectrum changes, we also showed the decreasing richness of small pelagic fish diets over time. This result is in agreement with observed and modelled changes in the composition and the phenology of zooplankton in Mediterranean areas surrounding the Gulf of Lions (Balearic Sea: Fernández de Puelles \& Molinero 2008, Auger et al. 2014; Ligurian Sea: Molinero et al. 2005, 2008). Recent low prey diversity and small prey sizes suggest that recent environmental changes affected the planktonic production. Our study, despite some missing values in some years, showed a decreasing trend in $\delta^{13} \mathrm{C}$ values for zooplankton. This is also in agreement with other studies, which underlined similar isotopic values in 2010 and in 2014, and most importantly strictly lower values in 2010 than in 2004 and 2005 (Bănaru et al. 2013, Espinasse et al. 2014, Strady et al. 2015). Although isotopic variations may result from a multitude of drivers, strong differences documented in this study could support important changes in the planktonic community and/or in the organic matter sources. Auger et al. (2014) showed that climatic and environmental variations may induce changes in size structure of the plankton community, while Rau et al. (1990) showed that small phytoplankton (pico- and nanophytoplankton) had lower $\delta^{13} \mathrm{C}$ values than microphytoplankton. Interestingly, the possible reduction in $\delta^{13} \mathrm{C}$ values for zooplankton between $2004 / 2005$ and 2010 corresponds to the period of drastic changes in small pelagic fish populations (Van Beveren et al. 2014). As already observed in the Benguela ecosystem, where shifts between anchovy and sardine regimes were caused by changes in the availability of mesozooplankton prey mediated through changes in environmental conditions (Shannon et al. 2004), growth and condition of sardine and secondarily anchovy in the Gulf of Lions are also likely to be mediated by bottom-up control.

\section{CONCLUSION}

This study supports the hypothesis that changes in small pelagic fish growth, size and body condition could be due to bottom-up control characterized by changes in food availability and/or increasing potential trophic competition, 2 factors that might influence feeding success and energy allocation. Our results illustrate the utility of comparing feeding habits between periods using a combination of short (stomach content) and longer-term (SIA) indicators. This not only helps to understand the current ecosystem fluctuations in the Gulf of Lions, but also provides insight into the trophic dynamics of the pelagic ecosystem, possibly allowing more efficient monitoring of marine food-web evolution.

Acknowledgements. We thank the captain and crew of RV 'L'Europe', as well as all the scientists onboard for their assistance during PELMED surveys. PELMED surveys are co-financed by the EU through the Data Collection Framework. We also thank Isabel Palomera for providing Spanish data, Mireille Harmelin-Vivien for comments on previous works, Gaël Guillou for performing stable isotope analyses and Virginie Marques for artwork help. This research was partly funded through the EcoPelGol project (Study of the Pelagic ecosystem in the Gulf of Lions), financed by France Filière Pêche (FFP) and partly funded through Policy-oriented marine Environmental Research for the Southern EUropean Seas (PERSEUS) financed by FP7 EU project, End-to-end Modelling and Indicators for BIOdiversity Scenarios (EMIBIOS) financed by the Fondation pour la Recherche et la Biodiversité (FRB) and Intéractions plankton - planctonophages (IPP) financed by WP2 Marine Ecosystems Réponse dans l'Expérience de la Méditerranée (MERMEX). P.B. acknowledges doctoral fellowship support from the French Ministère de l'Education Nationale, de la Recherche et de la Technologie. 


\section{LITERATURE CITED}

Alheit J, Niquen M (2004) Regime shifts in the Humboldt Current ecosystem. Prog Oceanogr 60:201-222

> André G, Garreau P, Garnier V, Fraunié P (2005) Modelled variability of the sea surface circulation in the northwestern Mediterranean Sea and in the Gulf of Lions. Ocean Dyn 55:294-308

Auger PA, Ulses C, Estournel C, Stemmann L, Somot S, Diaz F (2014) Interannual control of plankton communities by deep winter mixing and prey/predator interactions in the NW Mediterranean: results from a 30-year 3D modeling study. Prog Oceanogr 124:12-27

Ayón P, Swartzman G, Espinoza P, Bertrand A (2011) Longterm changes in zooplankton size distribution in the Peruvian Humboldt Current System: conditions favouring sardine or anchovy. Mar Ecol Prog Ser 422:211-222

Bănaru D, Mellon-Duval C, Roos D, Bigot JL and others (2013) Trophic structure in the Gulf of Lions marine ecosystem (north-western Mediterranean Sea) and fishing impacts. J Mar Syst 111-112:45-68

Bănaru D, Carlotti F, Barani A, Grégori G, Neffati N, Harmelin-Vivien M (2014) Seasonal variation of stable isotope ratios of size-fractionated zooplankton in the Bay of Marseille (NW Mediterranean Sea). J Plankton Res 36: 145-156

Beaugrand G, Brander KM, Alistair Lindley J, Souissi S, Reid PC (2003) Plankton effect on cod recruitment in the North Sea. Nature 426:661-664

- Blanchard JL, Jennings S, Holmes R, Harle J and others (2012) Potential consequences of climate change for primary production and fish production in large marine ecosystems. Philos Trans R Soc Lond B Biol Sci 367: 2979-2989

Borme D, Tirelli V, Brandt SB, Fonda Umani S, Arneri E (2009) Diet of Engraulis encrasicolus in the northern Adriatic Sea (Mediterranean): ontogenetic changes and feeding selectivity. Mar Ecol Prog Ser 392:193-209

Breiman L, Friedman JH, Olshen RA, Stone CJ (1984) Classification and regression trees. Chapman \& Hall, London

> Brosset P, Ménard F, Fromentin JM, Bonhommeau S and others (2015) Influence of environmental variability and age on the body condition of small pelagic fish in the Gulf of Lions. Mar Ecol Prog Ser 529:219-231

Caut S, Roemer GW, Donlan CJ, Courchamp F (2006) Coupling stable isotopes with bioenergetics to estimate interspecific interactions. Ecol Appl 16:1893-1900

$>$ Cortés E (1997) A critical review of methods of studying fish feeding based on analysis of stomach contents: application to elasmobranch fishes. Can J Fish Aquat Sci 54:726-738

$>$ Costalago D, Palomera I (2014) Feeding of European pilchard (Sardina pilchardus) in the northwestern Mediterranean: from late larvae to adults. Sci Mar 78:41-54

Costalago D, Navarro J, Álvarez-Calleja I, Palomera I (2012) Ontogenetic and seasonal changes in the feeding habits and trophic levels of two small pelagic fish species. Mar Ecol Prog Ser 460:169-181

$>$ Cucherousset J, Villéger S (2015) Quantifying the multiple facets of isotopic diversity: new metrics for stable isotope ecology. Ecol Indic 56:152-160

> Cury P, Shannon L (2004) Regime shifts in upwelling ecosystems: observed changes and possible mechanisms in the northern and southern Benguela. Prog Oceanogr 60: 223-243

> Darnaude AM, Salen-Picard C, Polunin NVC, Harmelin-
Vivien ML (2004) Trophodynamic linkage between river runoff and coastal fishery yield elucidated by stable isotope data in the Gulf of Lions (NW Mediterranean). Oecologia 138:325-332

> DeNiro MJ, Epstein S (1978) Influence of diet on the distribution of carbon isotopes in animals. Geochim Cosmochim Acta 42:495-506

- Dumont HJ, de Velde IV, Dumont S (1975) The dry weight estimate of biomass in a selection of Cladocera, Copepoda and Rotifera from the plankton, periphyton and benthos of continental waters. Oecologia 19:75-97

> Espinasse B, Harmelin-Vivien M, Tiano M, Guilloux L, Carlotti F (2014) Patterns of variations in C and N stable isotope ratios in size-fractionated zooplankton in the Gulf of Lion, NW Mediterranean Sea. J Plankton Res 36: $1204-1215$

> Fernández de Puelles MLF, Molinero JC (2008) Decadal changes in hydrographic and ecological time-series in the Balearic Sea (western Mediterranean), identifying links between climate and zooplankton. ICES J Mar Sci 65:311-317

GFCM (General Fisheries Commission for the Mediterranean) (2014) Report of the Working Group on Stock Assessment of Small Pelagic Species. GFCM, Rome

GFCM (General Fisheries Commission for the Mediterranean) (2015) Report of the Working Group on Stock Assessment of Small Pelagic Species. GFCM, Rome

> Hardin G (1960) The competitive exclusion principle. Science 131:1292-1297

- Harmelin-Vivien M, Loizeau V, Mellon C, Beker B and others (2008) Comparison of $\mathrm{C}$ and $\mathrm{N}$ stable isotope ratios between surface particulate organic matter and microphytoplankton in the Gulf of Lions (NW Mediterranean). Cont Shelf Res 28:1911-1919

Hill MO (1973) Diversity and evenness: a unifying notation and its consequences. Ecology 54:427-432

Hobson KA (1999) Tracing origins and migration of wildlife using stable isotopes: a review. Oecologia 120:314-326

Hyslop EJ (1980) Stomach contents analysis - a review of methods and their application. J Fish Biol 17:411-429

Jackson AL, Inger R, Parnell AC, Bearhop S (2011) Comparing isotopic niche widths among and within communities: SIBER - Stable Isotope Bayesian Ellipses in R. J Anim Ecol 80:595-602

> Le Bourg B, Bănaru D, Saraux C, Nowaczyk A and others (2015) Trophic niche overlap of sprat and commercial small pelagic teleosts in the Gulf of Lions (NW Mediterranean Sea). J Sea Res 103:138-146

Lefevre D, Minas HJ, Minas M, Robinson C, Williams PJ Le B, Woodward EMS (1997) Review of gross community production, primary production, net community production and dark community respiration in the Gulf of Lions. Deep-Sea Res II 44:801-832

Matthews B, Mazumder A (2004) A critical evaluation of intrapopulation variation of $\delta^{13} \mathrm{C}$ and isotopic evidence of individual specialization. Oecologia 140:361-371

Medina A, Goñi N, Arrizabalaga H, Varela JL (2015) Feeding patterns of age-0 bluefin tuna in the western Mediterranean inferred from stomach-content and isotope analyses. Mar Ecol Prog Ser 527:193-204

Millot C (1990) The Gulf of Lions' hydrodynamics. Cont Shelf Res 10:885-894

Minas M, Minas H (1989) Primary production in the Gulf of Lions with considerations to the Rhone River inputs. Water Pollut Res Rep 32:112-125 
Molinero JC, Ibanez F, Nival P, Buecher E, Souissi S (2005) North Atlantic climate and northwestern Mediterranean plankton variability. Limnol Oceanogr 50:1213-1220

Molinero JC, Ibanez F, Souissi S, Buecher E, Dallot S, Nival $P$ (2008) Climate control on the long-term anomalous changes of zooplankton communities in the northwestern Mediterranean. Glob Change Biol 14:11-26

Newsome SD, Martinez del Rio C, Bearhop S, Phillips DL (2007) A niche for isotopic ecology. Front Ecol Environ 5: 429-436

Nikolioudakis N, Isari S, Pitta P, Somarakis S (2012) Diet of sardine Sardina pilchardus: an 'end-to-end' field study. Mar Ecol Prog Ser 453:173-188

Palomera I, Olivar MP, Salat J, Sabatés A, Coll M, García A, Morales-Nin B (2007) Small pelagic fish in the NW Mediterranean Sea: an ecological review. Prog Oceanogr 74: 377-396

Pethybridge $\mathrm{H}$, Bodin N, Arsenault-Pernet EJ, Bourdeix JH and others (2014) Temporal and inter-specific variations in forage fish feeding conditions in the NW Mediterranean: lipid content and fatty acid compositional changes. Mar Ecol Prog Ser 512:39-54

Pinkas L, Oliphant M, Iverson I (1971) Food habits of albacore, bluefin tuna, and bonito in California waters. Calif Fish Game Fish Bull 152:1-105

Plounevez S, Champalbert G (2000) Diet, feeding behaviour and trophic activity of the anchovy (Engraulis encrasicolus, L.) in the Gulf of Lions (Mediterranean Sea). Oceanol Acta 23:175-192

Post DM, Layman CA, Arrington DA, Takimoto G, Quattrochi J, Montaña CG (2007) Getting to the fat of the matter: models, methods and assumptions for dealing with lipids in stable isotope analyses. Oecologia 152:179-189

Rau GH, Teyssie JL, Rassoulzadegan F, Fowler SW (1990) ${ }^{13} \mathrm{C} /{ }^{12} \mathrm{C}$ and ${ }^{15} \mathrm{~N} /{ }^{14} \mathrm{~N}$ variations among size-fractionated marine particles: implications for their origin and trophic relationships. Mar Ecol Prog Ser 59:33-38

Sánchez Gómez S (2013) Advances in the knowledge of condition and energy budgets along the life cycle of two small pelagic fishes from the Western Mediterranean. MSc thesis, Universitat de Barcelona

Saraux C, Fromentin JM, Bigot JL, Bourdeix JH and others (2014) Spatial structure and distribution of small pelagic fish in the northwestern Mediterranean Sea. PLoS ONE 9:e111211

Schwartzlose RA, Alheit J, Bakun A, Baumgartner TR and others (1999) Worldwide large-scale fluctuations of sardine and anchovy populations. S Afr J Mar Sci 21:289-347

Shannon LJ, Field JG, Moloney CL (2004) Simulating anchovy-sardine regime shifts in the southern Benguela ecosystem. Ecol Model 172:269-281

> Strady E, Harmelin-Vivien M, Chiffoleau JF, Veron A, Tronczynski J, Radakovitch O $(2015){ }^{210} \mathrm{Po}$ and ${ }^{210} \mathrm{~Pb}$ trophic transfer within the phytoplankton-zooplankton-anchovy/ sardine food web: a case study from the Gulf of Lion (NW Mediterranean Sea). J Environ Radioact 143:141-151

Sweeting CJ, Jennings S, Polunin NVC (2005) Variance in isotopic signatures as a descriptor of tissue turnover and degree of omnivory. Funct Ecol 19:777-784

Syväranta J, Lensu A, Marjomäki TJ, Oksanen S, Jones RI (2013) An empirical evaluation of the utility of convex hull and standard ellipse areas for assessing population niche widths from stable isotope data. PLoS ONE 8: e56094

Tudela S, Palomera I (1997) Trophic ecology of the European anchovy Engraulis encrasicolus in the Catalan Sea (northwest Mediterranean). Mar Ecol Prog Ser 160: 121-134

Turner TF, Collyer ML, Krabbenhoft TJ (2010) A general hypothesis-testing framework for stable isotope ratios in ecological studies. Ecology 91:2227-2233

Van Beveren E (2016) Population changes in small pelagic fish of the Gulf of Lions: a bottom-up control? PhD thesis, Université de Montpellier

Van Beveren E, Bonhommeau S, Fromentin JM, Bigot JL and others (2014) Rapid changes in growth, condition, size and age of small pelagic fish in the Mediterranean. Mar Biol 161:1809-1822

> Van Beveren E, Fromentin JM, Rouyer T, Bonhommeau S, Brosset P, Saraux C (2016) The fisheries history of small pelagics in the northern Mediterranean. ICES J Mar Sci 73:1474-1484

Vander Zanden MJ, Rasmussen JB (1999) Primary consumer $\delta^{13} \mathrm{C}$ and $\delta^{15} \mathrm{~N}$ and the trophic position of aquatic consumers. Ecology 80:1395-1404

> Vander Zanden MJ, Rasmussen JB (2001) Variation in $\delta^{15} \mathrm{~N}$ and $\delta^{13} \mathrm{C}$ trophic fractionation: implications for aquatic food web studies. Limnol Oceanogr 46:2061-2066

> Vijverberg J, Frank TH (1976) The chemical composition and energy contents of copepods and cladocerans in relation to their size. Freshw Biol 6:333-345

- Wiegand MD (1996) Composition, accumulation and utilization of yolk lipids in teleost fish. Rev Fish Biol Fish 6: 259-286

Zarubin M, Farstey V, Wold A, Falk-Petersen S, Genin A (2014) Intraspecific differences in lipid content of calanoid copepods across fine-scale depth ranges within the photic layer. PLoS ONE 9:e92935 


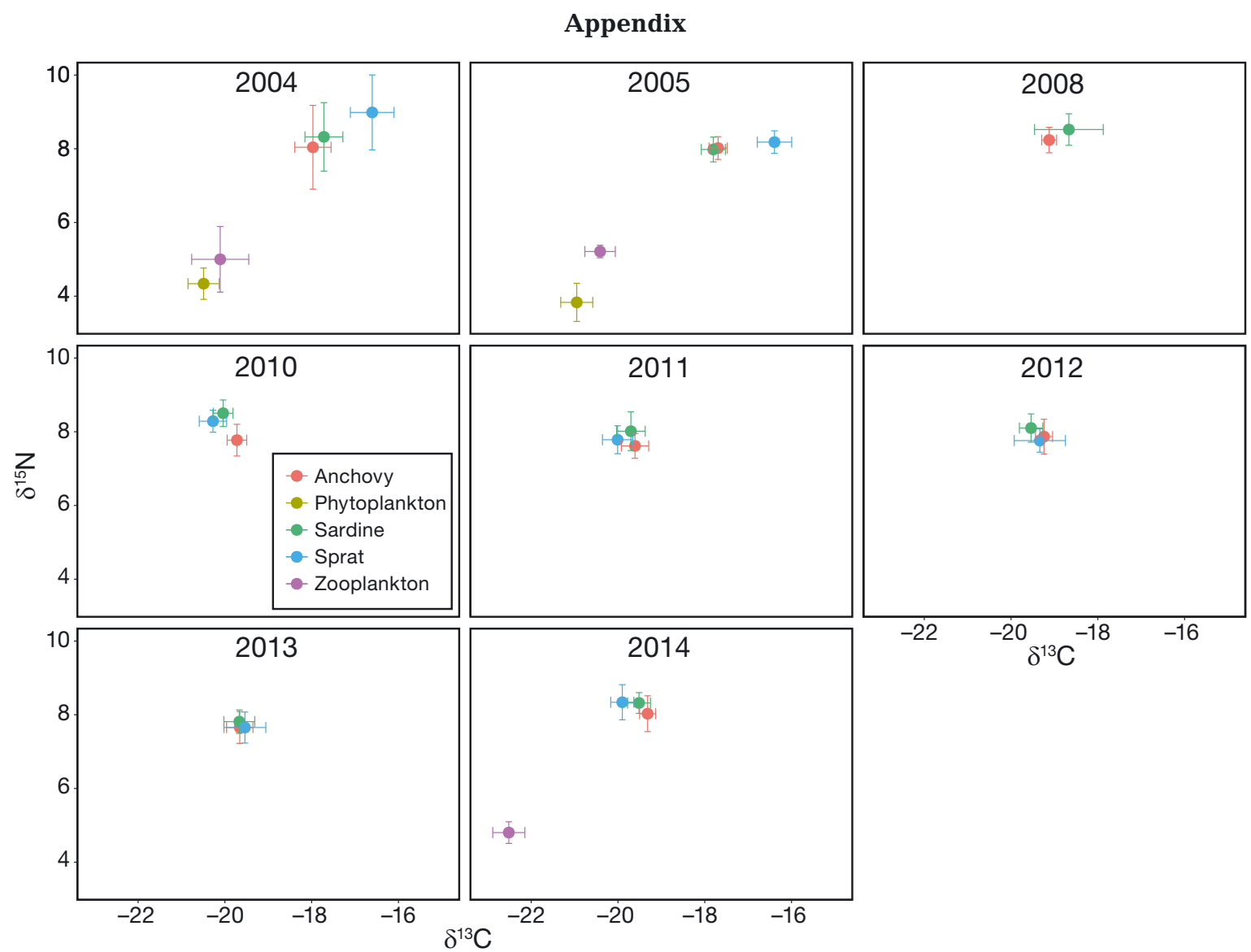

Fig. A1. Dual isotope plot representing the different small pelagic fish species sampled each year and the basal trophic levels (phytoplankton and zooplankton). All of the different groups are represented by mean $\delta^{13} \mathrm{C}$ and $\delta^{15} \mathrm{~N}$ values $( \pm \mathrm{SD})$

Editorial responsibility: Stylianos Somarakis, Heraklion, Greece
Submitted: March 29, 2016; Accepted: June 8, 2016

Proofs received from author(s): July 13, 2016 